\title{
Analysis of Usage Consulting Services in Agricultural Enterprises of Uzbekistan
}

\author{
G.A.Ibragimov \\ Samarkand Agricultural Institute \\ 140103. 77, M.Ulugbek street, Samarkand, Uzbekistan \\ Email: gaibragimov@yahoo.com
}

Received: May 18, 2013 Accepted: June 02, 2013 DOI: 10.5296/jpag.v3i2.3976

\begin{abstract}
There are many factors for influencing Agricultural enterprises efficiency, one of them is consulting (extension) service. In this article described and analyzed organizing ways of consulting service, its role, importance and ways of improving in Agriculture. Research provided through questionnaire and participations was 100 Agricultural enterprises.
\end{abstract}

Keywords: Agricultural enterprises, services entities, consulting (extension) service, usage of consulting service. 


\section{Introduction}

Farming - a new form of agricultural activity in Uzbekistan for the 21 st century. Uzbek government always pays attention to the developing of farms and this gave already own results. Today the farmers play a significant role in agricultural production in Uzbekistan.

Farms produced 3,350 thousand tons of raw cotton ${ }^{1}$, and 7170 tons of grain $^{2}$ in 2012 [Karimov, 2012]. Although the results significantly, but scientific research shows these figures should be even more. Tests revealed that the head of farms were representatives of different professions. This was the reason for the initial stage of farms decreases the efficiency in production. In many countries that developed agricultural production found an original solution for this problem: consulting service for agricultural enterprises.

Today more than 318 consulting centers in the Uzbekistan providing consulting services to farmers, but this are not enough for efficiency agricultural enterprises. For this reason pay attention to help the expansion of consulting centers on the Decree of the President of the Republic of Uzbekistan "On measures to improve the organization of activities and the development of farming in Uzbekistan" (№ ПФ-4478 Date of adoption of 22.10.2012, the date of entry into force 10.22.2012).

Market economy conditions, when the growth of agricultural production is associated with difficulties when there is fierce competition among agricultural producers, both within the country and between countries, when there is a massive ruin of farmers working inefficiently, a special role is assigned to agricultural consulting services. Tasks of service - help to address rural producers through the integration of education, agricultural science in the production, to interact with the organizations that influence the development of the agricultural sector [Torikov, 2004].

One of the major problems of the agroindustrial complex of the Republic is to create an efficient, flexible and responsive to new developments social market economic system. One must consider the principal features of modern agriculture, among them - the small size of production, which does not allow a particular commodity producers conduct research with internal resources, implement research and development, as it can be done in large industrial plants. Hence the need to create a special system providing communicating scientific and technical developments, and any other information to agricultural producers. If we consider that the main factor ensuring that effective management solutions in the market environment, both at the head of the company, and at the level of regional and national authorities agribusiness in general, is a timely and accurate information, the actual is the rational organization of information and consultancy services in the production management system [Yakimova, 2004].

However, research works have been devoted to more problems not directly related to the study of the needs of agricultural producers in the information and consulting services, so that in the course of the investigation it was necessary to turn to the works of local and foreign scientists dedicated to the organization of information and advisory services of agricultural

\footnotetext{
${ }^{1}$ Karimov I.A. President's greeting to cotton growers of Uzbekistan. www.president.uz 19.10.2012.

${ }^{2}$ Karimov I.A. President's greeting to grain growers of Uzbekistan. www.president.uz 13.07.2012.
} 
producers, namely Alexanov D.S. [2], Axinn G.H. [3], van den Ban A.W. [15], Havercamp M. [6], Hoffmann V. [7], Swanson V.E. [13], Bautin V.M. [4], Kozlov V. [11], Korolkov A.F. [8], Koshelev V.M. $[9,10]$ and others. In the works of these authors emphasized the importance of identifying the needs of agricultural producers in the relevant information and new knowledge, to improve efficiency and speed up the development of agricultural production, however, the problem of assessing needs of agricultural producers in the information and advisory services remains unresolved.

\section{Materials and methods}

Article based on of results of research analyzing economic efficiency of usage services on Agricultural Enterprises of the Republic of Uzbekistan. During preparation of article used materials of research, scientific works of national and foreign researchers, also statistical materials of Ministry of Agriculture and Water resources, Ministry of Economics, State Committee of Statistics and web sites of government (www.press-service.uz, www.agro.uz, www.gov.uz). Main materials are gathered through questionnaire, used methods Chi-square, Excel software. All scientific conclusions are based on results of research.

\section{Results and analysis}

Researches showed that during the analyzed period 2006-2012 the number of centers of consulting services varied in different levels. In the research period the number of all types of service enterprises increased rhythmically, but analysis of the amount of consulting services showed different results. It shows that activity of that type of the enterprise is going irregularly (See figure 1).

If there was a number of enterprises of all types of services - 7513 in 2006 and increased by 10,880 in 2012, the largest increase was 2661 in the period 2006-2007. In the period 2006-2007, the number of centers of consulting services decreased 22. The figure shows that, after 2009, the number of centers of consulting services is increasing tendency.

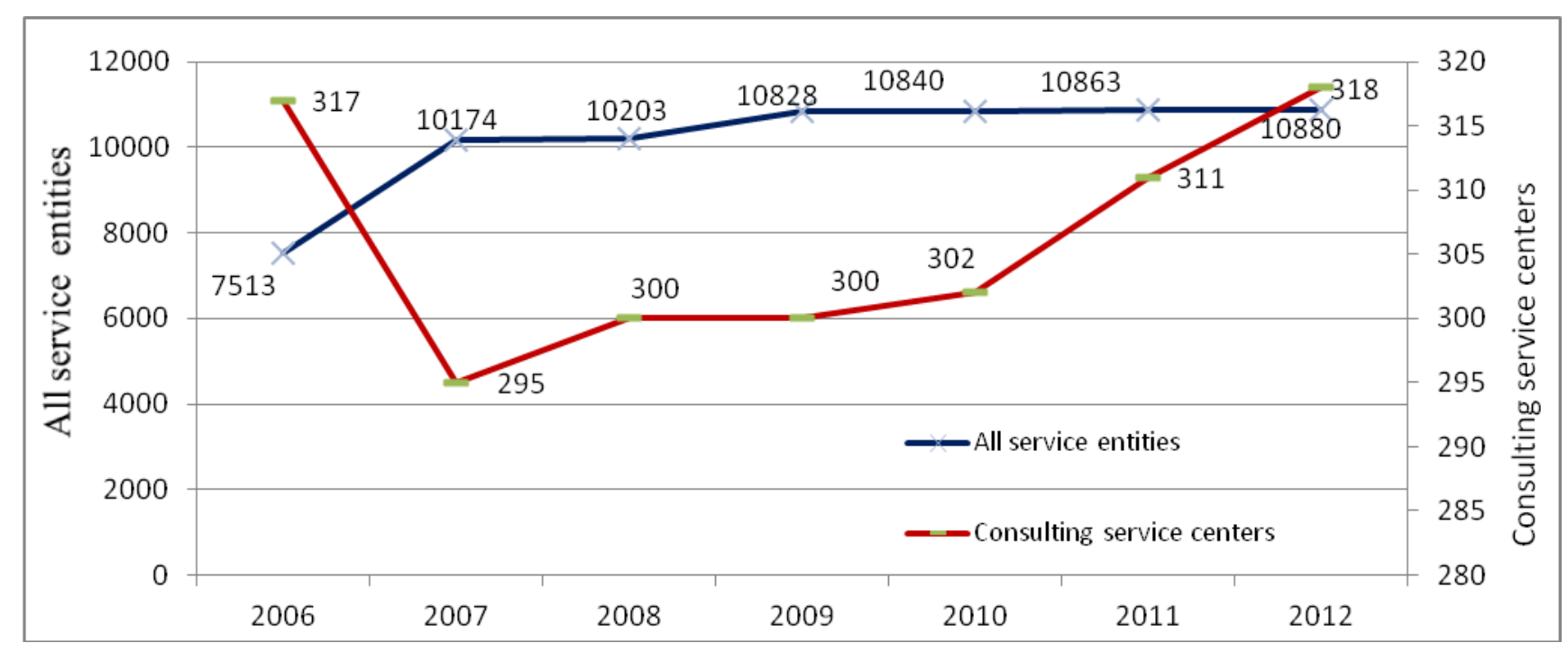

Figure 1. Analysis of service entities and consulting centers in Uzbekistan, 2006-2012. 


\section{Macrothink}

Journal of Public Administration and Governance

ISSN 2161-7104

2013, Vol. 3, No. 2

Increasing quantity of center of consulting services during the 2006-2012 periods was just 1 . Rising quantity of consulting service centers and service enterprises, that can be evaluated by the Government's attention to the agricultural enterprises and service enterprises.

Growth of quantity of centers which representing consulting services has to influence to the quality of service, it is also one objective of research. Changes in quantity of consulting centers in its queue influenced to the number of contracts between them and agricultural enterprises (See figure 2).

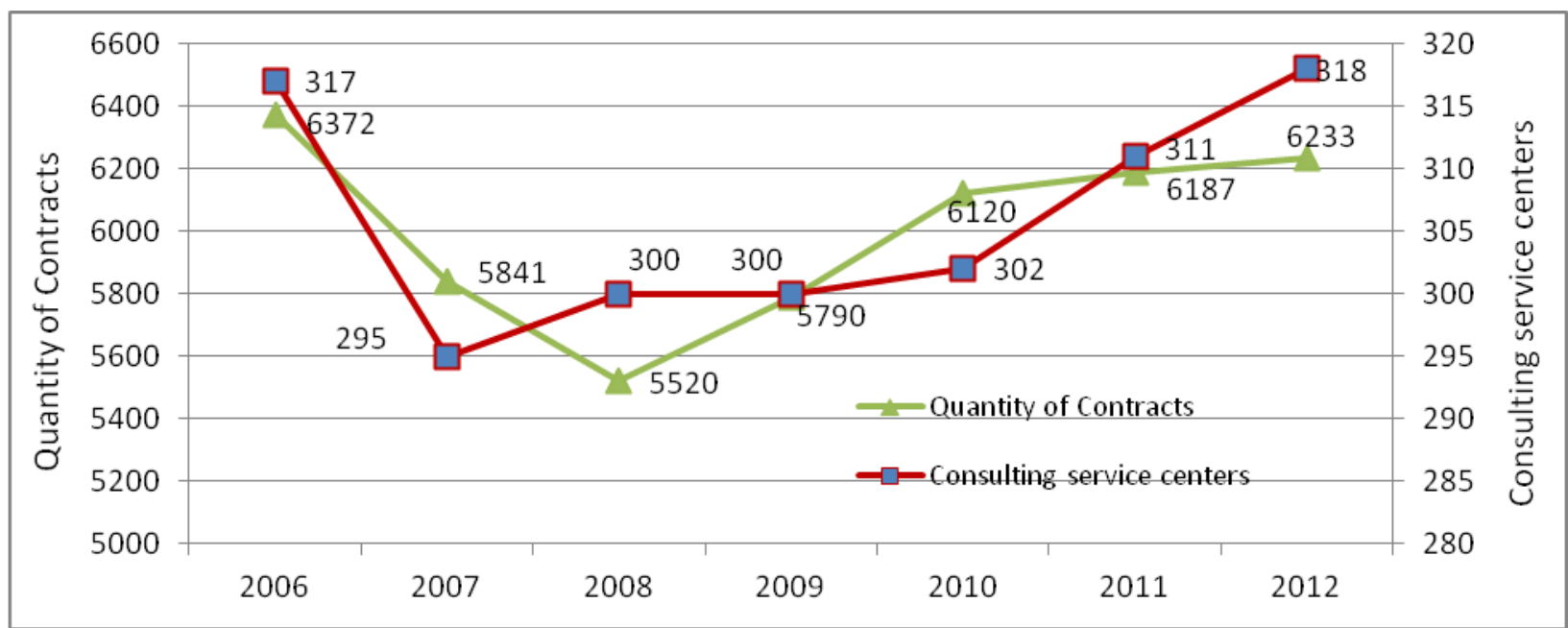

Figure 2. Analysis of consulting centers and quantity of contracts in Uzbekistan, 2006-2012.

Signed contracts have tendency of changes during period 2006-2012, more contracts are signed in 2008: 5520 contracts and less contracts are signed in 2006: 6372 contracts. It influenced decrease of quantity of consulting services and optimization of farms in this period.

Signed contracts in consulting centers with agricultural enterprises did not give us necessary information during the analysis, so we examined the average value of the contract for period 2006-2012.

Analysis of average value of contract showed that at the center of consulting services also has own drawbacks (See figure 3). 


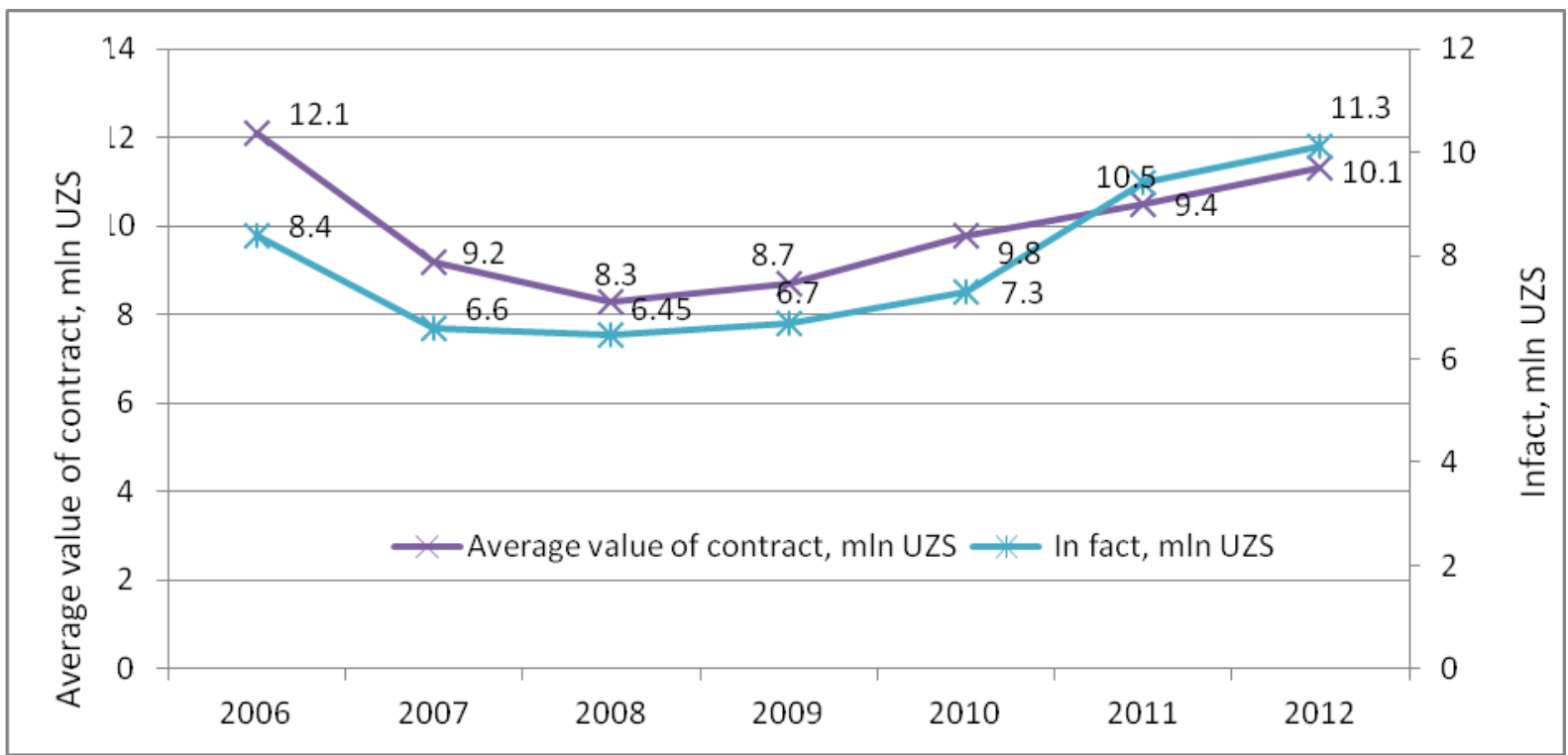

Figure 3. Analysis of average value of contracts in Uzbekistan, 2006-2012.

We had observed changes in the position of average value of contract, if in 2006 average value of per contract was $12,1 \mathrm{mln}$. UzS and in 2012, it was 11,3 mln. UzS. The lowest average value of per contract observed in 2008, 8,3 mln UzS. In particular, such a situation was observed in the actual performance of contracts.

This shows that the demand for consulting services is low among agricultural enterprises and in result value of contracts is not performed at centers of consulting services.

To clarify the situation, why there are low demands for the consulting services in Agriculture, we conducted questionnaire from 100 participants in agricultural enterprises of different specialties, forms of activity and from different regions of Uzbekistan (2012).

During research analyzed usage of consulting service of 100 agricultural enterprises in Uzbekistan through questionnaire (See table 1). 
Table 1. Analyze of usage consulting service in the agricultural entities based on questionnaire $^{3}$

\begin{tabular}{|c|c|c|c|c|c|c|c|}
\hline \multirow{2}{*}{$\begin{array}{c}\text { Type of } \\
\text { agricultural } \\
\text { entities }\end{array}$} & & \multicolumn{6}{|c|}{ Agricultural activity spheres } \\
\hline & & $\begin{array}{l}\text { Cotton } \\
\text { growing }\end{array}$ & $\begin{array}{l}\text { Grain } \\
\text { growing }\end{array}$ & $\begin{array}{l}\text { Oleri- } \\
\text { culture }\end{array}$ & $\begin{array}{l}\text { Horti- } \\
\text { culture }\end{array}$ & $\begin{array}{l}\text { Vini- } \\
\text { culture }\end{array}$ & $\begin{array}{l}\text { Cattle } \\
\text { breeding }\end{array}$ \\
\hline \multirow[t]{4}{*}{ Households } & Not answered & 0 & 4 & 4 & 0 & 4 & 0 \\
\hline & No & 0 & 0 & 2 & 0 & 2 & 0 \\
\hline & Yes & 0 & 3 & 3 & 0 & 1 & 0 \\
\hline & All & 0 & 7 & 9 & 0 & 7 & 0 \\
\hline \multirow[t]{7}{*}{ Farms } & Not answered & 9 & 21 & 12 & 8 & 7 & 0 \\
\hline & No & 17 & 33 & 21 & 17 & 8 & 11 \\
\hline & Yes & 7 & 25 & 15 & 9 & 15 & 5 \\
\hline & Yes, through & & & & 0 & 1 & 0 \\
\hline & Internet & 0 & 1 & 0 & & & \\
\hline & All & 33 & 80 & 48 & 34 & 31 & 16 \\
\hline & otal & 33 & 87 & 57 & 34 & 38 & 16 \\
\hline
\end{tabular}

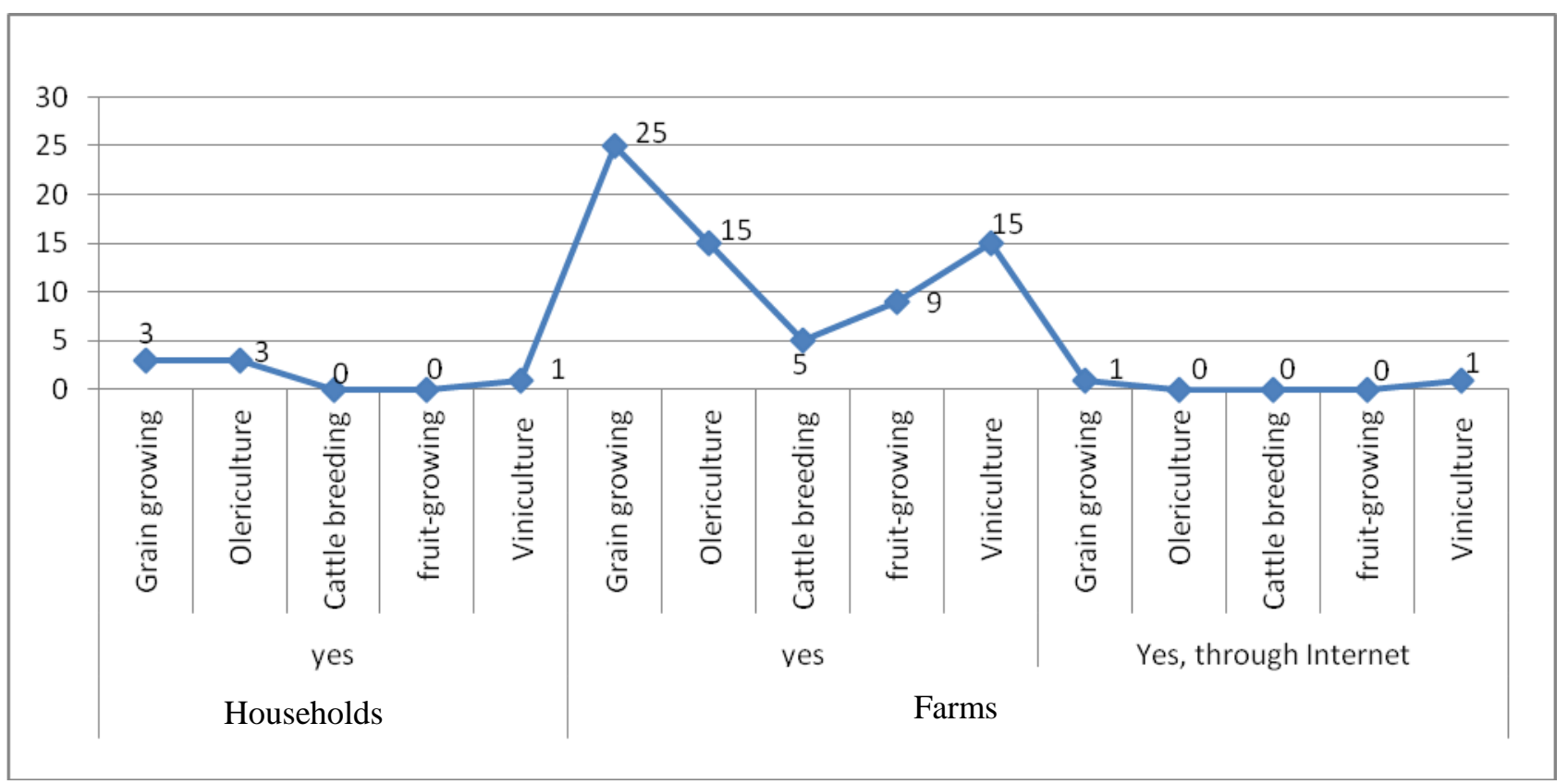

Figure 4. Analysis of usage consulting service in Agricultural entities (100 questionnaire participations) $)^{4}$

Participated agribusiness entities in questionnaire were households -9 , farms -91 . Main analyzed activities which using Consulting services in these entities are cotton growing, grain growing, olericulture, horticulture, viniculture, cattle breeding. Results, more usage from service among households 3 , among farms 25 enterprises (See figure 4).

\footnotetext{
3 Authors analysis based on results of questionnaire

4 Authors analysis based on results of questionnaire
} 


\section{Macrothink}

This analysis shows that the demand for consulting services is available, but the demand is very low. The reason for the low demand is the solvency problems of agricultural enterprises, which are considered low-profit sectors. Agricultural enterprise did not want use paid services like consulting service, contrary they satisfying their demand by using other methods, such as using the Internet.

\section{Conclusion}

Agricultural enterprises are not using enough consulting services in the Republic of Uzbekistan. This type of service is conjunctive between the service of science and agricultural production, also plays a significant role in increasing the efficiency of agricultural producers. On this, the improvement consulting services makes it possible to use the unused capacity, in addition we've can completely use work of scientists of agricultural universities in the country, in the end results will increase efficiency of agriculture. The analysis showed that in the agricultural sector demand for consulting services is very low. Although there are demand for services in agricultural enterprises', but they are used with other methods to meet the demand. The main cause of this is a chargeable service and is a low-profit sector avoids the payment of many farms. As such, we offer to create a service as extension service from state and local budget like countries which agriculture developed (US and Europe).

\section{References}

1. DECREE OF THE PRESIDENT of the Republic of Uzbekistan ПФ - \#4478. On measures to improve the organization of activities and the development of farming in Uzbekistan (Date of adoption of 22.10.2012, the date of entry into force 10.22.2012).

2. ALEXANOV D.S. Development of information and consulting service Russian agricultural sector: the contribution of the project ARIS / / Agrarian Russia. 2007. - Vol. 5. - pp.15-17.

3. AXINN G. H. Guide on alternative extension approaches. -Rome: FAO, 1988. $260 \mathrm{p}$.

4. Bautin V.M. The development of information and consulting services// Newsletter of the Ministry of Agriculture of the Russian Federation. -2001. - \#4.

5. IBRAGIMOV G.A. Role of consulting service in Agricultural infrastructure: materials of Republic conferences of researchers, $\mathrm{PhD}$ and doctoral students. Part 2. -T.: TSTU, 2007. -pp. 194-195 (In Uzbek).

6. HAVERCAMP M., Christiansen E., Mitchell P. Assessing Extension Internal Organizational Needs Through an Action Research and Learning Process // Journal of extension. - 2003, Vol. 41(5).

7. HOFFMANN V. Rural communication and extension. Script for module M 5121 WG / V. Hoffmann. Stuttgart. University of Hohenheim, 2003. - 166 p.

8. Karimov I.A. President's greeting to cotton growers of Uzbekistan. 
www.president.uz 19.10.2012.

9. Karimov I.A. President's greeting to grain growers of Uzbekistan. www.president.uz 13.07.2012.

10. KOROLKOV A.F. Types, forms and principles of information and advisory work in agriculture. Moscow: COK IKC AIC, 2004. - 20 p.

11. KOSHELEV V.M. Bases of creating and activity of extension service in Agribusiness - M.: Norma, 2011. - pp. 127. (In Russian).

12. KOSHELEV V.M. Building new agricultural enterprises in Russia: the role of extension service. Beyond Transition: Ten Years after the Fall of the Berlin Wall. UNDP/RBEC Policy Workshop, 11-15 October 1999, The Hague, The Netherlands

13. KOZLOV V.V. Problems and solutions to revive the agricultural consulting in Russia. -Moscow: FGNU "Rosinformagro-tech", 2002. - 204 p.

14. STOROJENKO V.A.. SLOVTSOV R.I., GOLENEVA L.M. Extension service in Agriculture. - M.: Russian Land, 2008. -103 p. (In Russian).

15. SWANSON, B. E. Improving agricultural extension. A reference manual. Rome: Food and Agriculture Organization of United Nations, 1997.

16. TORIKOV B.E., MALCEV V.F., KVITKO B.I. Information and consultancy services in Agriculture. -Bryansk: 2004. -140 p. (In Russian).

17. VAN DEN BAN A.W. Different ways of financing agricultural extension, "Agricultural Research \& Extension Network", Network paper No. 106, ISBN 085003488 4. 14-th European Seminar on Extension Education, Cracow, Poland, 1999

18. YAKIMOVA O. Formation information system management in the Agribusiness of the Republic of Mordovia // Basic research. - 2004. - Vol. 3 - pp. 52-56. (In Russian).

19. DATA MATERIALS of Ministry of Agriculture and Water resources, Ministry of Economics, State Committee of Statistics and web sites of government (www.press-service.uz, www.agro.uz, www.gov.uz, www.president.uz). 